порушення зв'язків між зонами кори головного мозку, що відповідають за мовлення. Досі досить гостро стоїть проблема диференціації алалії від інших порушень. Незважаючи на те, що вже існують досить точні праці з теми, спеціалісти все ще можуть помилятися, коли кордони між двома порушення психофізичного розвитку розмиті.

\title{
Література:
}

1. Визель Т.Г. Проблемы речового развития детей: в поисках. Московский институт психоанализа : Когито-Центр, 2019. 240 с.

2. Визель Т.Г., Клевцова С.В. Жёсткие и гибкие звенья развития речи (нейропсихологический и нейролингвистический аспекты). Специиальное образование. 2020. № 4. С. 157-170.

3. Зелінська-Любченко К. О. Історичний аспект вивчення проблеми локалізації уражень мовленнєвої системи при моторній алалії. Науковий часопис. Корекиійна педагогіка. 2016. № 31. С. 40-43.

4. Marcelo L. Berthier, Guadalupe Davila, Maria Jose Torres-Prioris, Ignacio Moreno-Torres та ін. Developmental Dynamic Dysphasia: Are Bilateral Brain Abnormalities a Signature of Inefficient Neural Plasticity? Frontiers in Human Neuroscience. 2020. № 73. URL: https://doi.org/10.3389/fnhum.2020.00073

5. Тищенко В.В. Диференційна діагностика алалії та інших порушень психофізичного розвитку. Науковий часопис. Актуальні проблеми логопедіï. 2011. № 18. С. 246-249.

DOI https://doi.org/10.30525/978-9934-26-146-6-42

\section{ЗАСВОСННЯ ГРАМАТИЧНОЇ КАТЕГОРІЇ ВІДМІНКА ШКОЛЯРАМИ ІЗ ТЯЖКИМИ ПОРУШЕННЯМИ МОВЛЕННЯ}

\section{Рібцун Ю. В.}

кандидат педагогічних наук, старший науковий співробітник, старший науковий співробітник відділу логопедії Інститут спеціальної педагогіки і психології імені Миколи Ярмаченка Начіональної академії педагогічних наук України м. Київ, Україна

Вектор удосконалення змісту сучасної освіти, у т. ч. й спеціальної, чітко спрямований на формування у школярів компетентностей, потрібних їм для ефективної подальшої самореалізації в суспільстві. 158 
У Концепції Нової української школи зазначено десять ключових компетентностей, які необхідні кожній людині для особистої реалізації, розвитку, активної громадянської позиції, успішності упродовж всього життя. Однією, чи не найважливішою, ключовою компетентністю $є$ спілкування державною мовою, що передбачає усвідомлення ролі ефективного спілкування, вміння висловлювати думки та почуття в усній і писемній формі шляхом використання слухання, говоріння, читання, письма, застосування мультимедійних засобів [1].

В основу повноцінного спілкування, окрім лексики та фонетики, закладена граматика - система морфологічних і синтаксичних одиниць, які об'єднують морфологію та синтаксис. Узгодження слів у реченні відбувається за допомогою використання граматичних категорій, зокрема відмінка - граматичної категорії самостійних частин мови (іменників, прикметників, числівників, займенників), яка виражає їх відношення до інших слів у словосполученні чи реченні (О. Авраменко, А. Грищенко, I. Дишлюк, С. Ігнатьєва, Л. Мацько, I. Муровцев, М. Плющ, О. Пономарів, Н. Тоцька, Н. Черсунова та ін.).

Відмінок $є$ основною ознакою, що характеризує іменник як член речення та виражає синтаксичні функції іменника щодо інших членів речення: лежить книжка (називний відмінок) - підмет, читаю книжку (знахідний відмінок) і захоплений книжкою (орудний відмінок) додаток, у книжці (місцевий відмінок) - обставина.

Граматичну категорію відмінка становлять сім грамем, які мають як загальні, так і специфічні значення: I) називний відмінок (початкова форма) вказує на лексичне найменування предмета (підручник) або явища реальної дійсності (веселка); II) родовий відмінок може вживатися при іменах, дієсловах і прислівниках. Родовий відмінок іменника, який залежить від дієслова, може вживатися: 1) для вираження прямого об'єкта: а) на який поширюється дія лише частково (дай олівия - в значенні на деякий час); б) при діссловах із заперечною часткою не (не читали книжки); 2) для позначення об'єкта після дієслів на позначення бажання, віддалення, сподівання тощо (чекати канікул); 3) для означення часу дії (цієї осені). Родовий відмінок іменника, який залежить від іменника, може вживатися: 1) для вираження різних означальних відношень, у т. ч. й приналежності (директор школи); 2) для означення суб'єкта, який діє, або є носієм певної ознаки (робота учнів); 3) для означення перелічуваних предметів, означення фрагмента або міри якоїсь речовини (частина школярів); 4) для вираження прямого об'єкта, на який спрямована дія (виконання вправи); 5) для означення предмета, 3 яким порівнюється інший предмет (цей третьокласник кмітливіший від ровесників). При прислівниках родовий відмінок 
вживається для означення предмета порівняння (корисніше иукерки); III) давальний відмінок найчастіше виступає при дієсловах, означає особу чи предмет, якому адресується дія (віддав вчительиі). У безособових реченнях давальний відмінок виражає суб'єкт стану (учням здавалось). У приіменному вживанні давальний відмінок може використовуватись: а) для вираження непрямого об'єкта (потрібно школярам); б) для вираження певних відношень 3 відтінком призначення (подяка вчителям); IV) знахідний відмінок має об'єктне значення (виготовляти поробку), може виступати в значенні міри, часу і простору (весь семестр). Знахідний відмінок іменника 3 прийменником може означати: а) місце (на стадіон); б) час (на хвилину); в) мету дії (пішли по гриби); V) орудний відмінок найчастіше виступає при дієсловах i 1) вказує на предмет як знаряддя дії (малював фарбами); 2) виражає: а) діючу особу або предмет при дієсловах пасивного стану, при безособових дієслівних формах на -но, -то, при дієприкметниках (написано ручкою); б) об'єкт дії (керувати гуртком); в) ознаку предмета в іменній частині складеного присудка (був другом); г) засіб пересування (іхати велосипедом); г) часові і просторові відношення (цілими днями); д) спосіб, характер дії і порівняння (меле язиком, як собака хвостом); е) співучасника виконувача дії (учитель $з$ учнями); VI) місцевий відмінок вживається як із дієсловами, так і з іменниками, та вказує на: а) предмет як на місце і час дії (лежить в пеналі); б) знаряддя дії (грати на скрипиі); в) образ і спосіб дії (на голові як у дурного на хаті); VII) кличний відмінок називає адресата дії. Серед відмінків називний i кличний є прямими, а інші - непрямими.

Вивчення тем, пов'язаних із відмінюванням, починається у третьому класі та триває упродовж всього шкільного навчання. Діти із тяжкими порушеннями мовлення (ТПМ), внаслідок специфічних особливостей усного мовлення, зокрема у: а) фонетико-фонематичній ланці: на рівні звуковимови - відсутність, подовження окремих звуків, повторення, спотворення, змішування, оглушення, одзвінчення, перестановки, додавання, пропуски, заміни навіть голосних звуків (у книжки - замість $y$ книжиі); на рівні складової структури - перестановки, повторення окремих складів, додавання, пропуски, злиття (у бібітека замість у бібліотеці); б) лексичній ланці - збідненість словника, незнання значення багатьох слів, плутання лексем (зошит - книжка - блокнот - альбом щоденник), заміна одних слів іншими, простішими за вимовою, заміна слів жестами; в) граматичній ланці - оволодіння системою морфем, відмінків, засвоєння навичок словозміни та словотворення відбувається 3 численними помилками, що виражається у недостатньому вмінні узгоджувати слова у роді, числі та відмінку (малюю олівиях, олівия, олівець 
замість олівиями), помилках у структуруванні речень, пропуску службових слів (пищу дошка замість на дошщі) тощо, мають значні труднощі під час оволодіння програмовим матеріалом з української мови, коли в практичні письмові роботи автоматично переноситься фонетичний принцип правопису, за яким написання слова відповідає його промовлянню («як говорю, так і пишу») (А. Винокур, Е. Данілавічютє, В. Ільяна, Г. Каше, Р. Левіна, 3. Мартинюк, О. Мастюкова, С. Соботович, Ю. Рібцун, В. Тищенко, Л. Трофименко та ін.).

Окрім наявних особливостей усного та писемного мовлення, школярі 3 ТПМ мають специфічні труднощі перебігу психічних пізнавальних процесів, пов'язаних 3 розумінням (деяка фрагментарність), запам'ятовуванням (швидке забування) навчального матеріалу, що потребує від педагога більш детального пояснення, покрокового алгоритму, застосування ейдетичних, емоційно насичених навчальних, ігрових методів і прийомів, які б покращили засвоєння дітьми системи досить абстрактних лінгвістичних понять [2].

Називний відмінок із відповідними запитаннями хто? та щзо? досить легко засвоюється учнями з мовленнєвими порушеннями, адже словоназва чітко асоціюється зі світом предметів, який зрозумілий дітям ще 3 раннього дитинства. Набагато складнішим є засвоєння значень та своєрідність інших відмінків, запитання яких є відмінними. Саме тому нами створена казка-розповідь про родину відмінків «Сім братів-

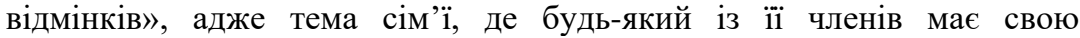
зовнішність, характер, уподобання, що не заважає їм жити дружно та допомагати один одному, є близькою досвіду кожного школяра:

В країні Морфології жила велика сім'я Іменників. У них народилось сім хлопчиків-відмінків із різними характерами та вподобаннями. Перший відмінок ще не народився, а вже думали яке ж дати йому ім'я. І вирішили назвати його Називним. Ось лежить новонароджений Називний відмінок у колисці, пальчиком навколо показує і запитує: «Хто? Що?» та називає все навколо. Другий відмінок народився і став Родовим, бо продовжив рід. Родовий відмінок весь час цікавився: «Кого? Чого?»

Третій відмінок, коли був малюком, що бачив, все просив: «Дай!» І його назвали Давальним. Підріс Давальний відмінок і сам став всім навколо все давати. Щедрий і добрий Давальний відмінок запитував: «Дати кому? Чому?»

Знахідний відмінок змалечку був бешкетником. Де він тільки не бував! Куди тільки не лазив! Щось знайде і додому несе. І прозвали його Знахідним. Знахідний відмінок що знайде, зразу не показує, а просить відгадати: «Я знайшов кого? Що?» Орудний відмінок швидко підріс. Він 
був кмітливим i працьовитим. Навчився орудувати різними інструментами. Став називатись Орудним. Орудний відмінок весь час запитував: «Орудую чим? Ким?»

Місцевий відмінок був дуже прив'язаним до рідного міста і ніколи не покидав його. Тому всі звали його Місиевим. Місцевому відмінку було завжди дуже цікаво знати про події в місті: «Де? На чому? На кому?»

Найменший, Кличний відмінок, користувався повагою як старших, так і друзів. До нього звертались за допомогою, кликали в гості. Стали звати його Кличним. І Кличний відмінок сам всіх закликав до себе в гості, найчастіше по імені. Мешканці країни Морфології були вдячні братам-відмінкам за те, що вони були такі дружні та завжди допомагали тим, хто прагнув вивчити українську мову.

Казка «Сім братів-відмінків», в образно-емоційній формі, допоможе учням із тяжкими порушеннями мовлення засвоїти назви відмінків, їх послідовність, краще зрозуміти семантику кожного 3 відмінків, що не тільки полегшить вивчення української мови, а й загалом сприятиме інтенсифікації та кращій вербалізації навчальної діяльності.

Все вищезазначене свідчить, що навчання в Новій українській школі - це цілеспрямований і спеціально організований процес оволодіння науково-практичними знаннями з різних галузей. Українська мова стає для школярів не лише засобом спілкування, але й предметом вивчення. Тому саме граматика $€$ тією основою, що дасть змогу учням з тяжкими порушеннями мовлення удосконалити як лінгвістичний, так i комунікативний компонент мовленнєвої діяльності, причому саме на свідомому рівні.

\section{Література:}

1. Концепція Нової української школи [Електронний ресурс]. Режим доступу до вид.: http://mon.gov.ua/activity/education/zagalna-serednya/ ua-sch-2016/konczepcziya.html

2. Рібцун Ю. В. (2020) Учні початкових класів із тяжкими порушеннями мовлення: навчання та розвиток. Львів : Світ 